\title{
Roles of glial cells in synapse development
}

\author{
Frank W. Pfrieger
}

Received: 26 December 2008/Revised: 20 January 2009/Accepted: 10 February 2009/Published online: 24 March 2009

(C) The Author(s) 2009. This article is published with open access at Springerlink.com

\begin{abstract}
Brain function relies on communication among neurons via highly specialized contacts, the synapses, and synaptic dysfunction lies at the heart of age-, disease-, and injury-induced defects of the nervous system. For these reasons, the formation-and repair-of synaptic connections is a major focus of neuroscience research. In this review, I summarize recent evidence that synapse development is not a cell-autonomous process and that its distinct phases depend on assistance from the so-called glial cells. The results supporting this view concern synapses in the central nervous system as well as neuromuscular junctions and originate from experimental models ranging from cell cultures to living flies, worms, and mice. Peeking at the future, I will highlight recent technical advances that are likely to revolutionize our views on synapse-glia interactions in the developing, adult and diseased brain.
\end{abstract}

Keywords Astrocytes - Neurodegeneration - Neuroglia · Neuromuscular junction - Schwann cells - Synaptogenesis

\section{Introduction}

Establishing and maintaining connections is crucial throughout life and often requires help from third parties. Increasing evidence suggests that this also applies to neurons: they seem to require support from glial cells to get

\section{F. W. Pfrieger $(\square)$}

Institute of Cellular and Integrative Neurosciences (INCI), CNRS UPR-3212, University of Strasbourg, 5, rue Louis Pasteur, 67084 Strasbourg, France

e-mail: fw-pfrieger@gmx.de; pfrieger@neurochem.u-strasbg.fr and stay in touch via synaptic contacts. These contacts, also called chemical synapses, probably represent the most highly specialized form of intercellular connections. They allow for the intercellular transmission of electrical signals with remarkable spatial and temporal precision in the micrometer and millisecond range, respectively, and an enormous bandwidth [1].

Synapse assembly requires a cascade of precisely timed and coordinated processes in two different partners, very much like what is needed during ordinary dating. In a first seek-and-find phase, neuronal partners meet their match, which depends on both attraction and good timing. In a second construction phase, the pre- and postsynaptic partners assemble the complex structures for transmitter-based communication. During a third phase, connections are finetuned to acquire their mature qualities. Finally, a fourth, break-up phase results in the elimination of unfit liaisons. Our understanding of the molecules and mechanisms that induce and mediate these different phases has greatly advanced in the last few years [2-14]. Here, I summarize the experimental evidence for glial contributions to each of the phases that has emerged since the last overviews were published $[15,16]$.

\section{Glial cells in touch with synapses}

The generic term "glial cells" is often used in this review, although in reality only subclasses of these cells are in touch with synapses. The terms glial cells or neuroglia, originally introduced by Rudolf Virchow to label "nerve glue" $[17,18]$, describe non-neuronal cells in nervous systems. In vertebrates, the four core types are astrocytes, oligodendrocytes, microglial cells in the central nervous system (CNS), and Schwann cells in the peripheral nervous 
system. In addition, there are ependymal cells and radial glia comprising cerebellar Bergmann glia, retinal Müller cells and hypothalamic tanycytes. Each of the glial cell types serves distinct functions (see [19-21] for astrocytes; [22-24] for microglia; [25] for oligodendrocytes; [26, 27] for radial glia, Müller cells).

Of these glial cell types, only astrocytes and perisynaptic (or terminal) Schwann cells (PSCs) contact synaptic connections in the CNS and peripheral nervous system, respectively, with micrometer-sized processes. This spatial arrangement was first described more than 30 years ago in pioneering ultrastructural studies [28] and has now been revealed in three dimensions (3D) in the cerebellum [29] and the hippocampus, where the size of the synapses and the extent of astrocytic contacts appear to correlate [30]. The intimate vicinity of synapses and astrocytes has led to speculations about the functional implications and inspired the concept of the "tripartite synapse", which regards glial cells as integral elements of synaptic connections [31]. There is increasing experimental support for this hypothesis. Recent studies show, for example, that glial cells influence synaptic function from the level of individual contacts [32] up to network activity that generates complex behavior [33, 34]. Overviews on this steadily growing field (Fig. 1) can be found in recent reviews [35-50].

\section{Do glial cells help to find a partner? Glia as match-maker}

The first hurdle to form a contact is to meet a (potential) partner. Glial cells facilitate this phase by providing

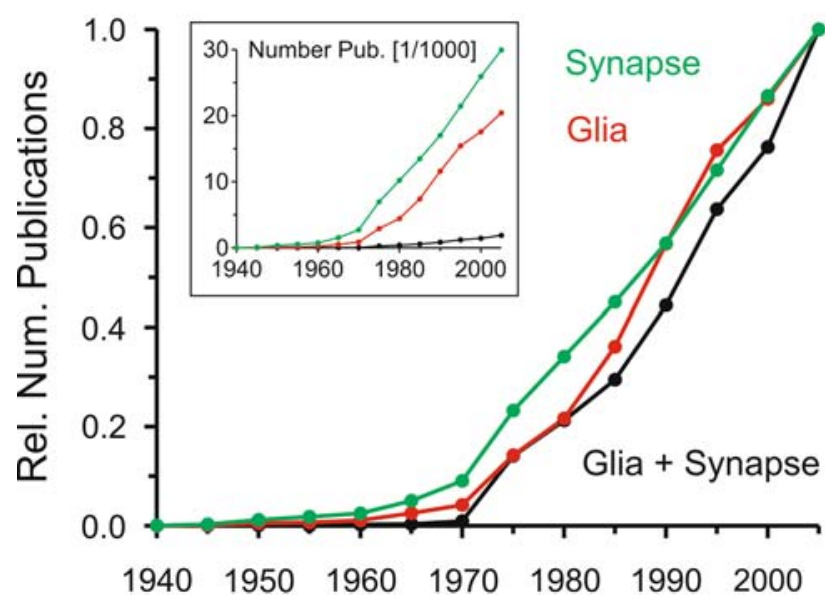

Fig. 1 Research on glia-synapse interactions. Number of publications in 5-year intervals normalized to paper counts in the last interval (2005-2010) related to synapses (green), glial cells (red), and synapses combined with glial cells (black). The numbers of different publications were extracted from PubMed searches on the indicated terms plus variations appearing in the titles or abstracts. Inset Absolute numbers of publications for each keyword guidance and promoting growth [51-53]. Direct confirmation that Schwann cells induce and guide the axons of motoneurons to muscle fibers was provided by an in vivo study on transgenic mice, where a constitutively active neuregulin receptor, ErbB2, was reversibly induced in Schwann cells [54]. This manipulation triggered the formation and growth of PSC processes and the concomitant formation of nerve terminal sprouts along glial processes.

Glial cells also guide and promote the growth of axons and dendrites in the CNS. The most recent advances are based on studies of transgenic mice, which allow for selective labeling and gene ablation in glial cells. Ango et al. [55] reported that axons of stellate, but not basket, cells grow along processes of Bergmann glia and establish their synaptic connections with Purkinje cells (PCs) at intersections with glial fibers. Ablation of Chl1, a member of the L1CAM family that is expressed by axons of stellate cells and by Bergmann glia, perturbed arborization and terminal formation of stellate cell axons, reduced their synaptic contacts with PCs, and led to age-dependent axonal degeneration [55]. A study on fluorescently labeled PCs and Bergmann glia in cultured cerebellar slices from postnatal mice showed that the dendritic tips of PCs grow along processes of radial/Bergmann glia [56], thus extending previous findings [57]. Glial promotion of dendrite growth and branching has been observed in cultures of neurons derived from human stem cells [58] and of immuno-isolated retinal ganglion cells (RGCs) [59] and PCs from postnatal rodents (Buard and Pfrieger, unpublished observation).

Results from several recent studies help to explain how glia influence neuronal growth. Further evidence for the involvement of the L1CAM family comes from a study in Drosophila, where the elimination of neuroglian ( $\mathrm{Nrg})$, a L1-like adhesion molecule, caused ectopic axonal sprouting and dendrite deformation in a specific sensory neuron [60]; this phenotype was only rescued if neuroglian was reexpressed in both neurons and associated glial cells. These results indicate that glial cells prevent the formation of ectopic sprouts and help establish the stereotypic morphology of neurons. A genetic screen for abnormal synapse distribution in mutant Caenorhabditis elegans revealed that contact establishment between two specific types of interneurons, AIY and RIA, requires the netrin receptor/UNC40 on axons of presynaptic AIY cells and its ligand netrin/ UNC-6 on the so-called cephalic sheath (CEPsh) glia [61]. The netrin-dependent function of CEPsh glia as guideposts can explain at least in part why growth and branching of axons and dendrites fail following the elimination of these cells [62].

Signals on the surface of glial cells are an obvious mechanism to promote and direct neuronal growth. The involvement of intracellular calcium signaling is indicated 
by a recent study on cocultures of hippocampal neurons and astrocytes from embryonic rats [63]. Retrovirus-mediated overexpression of an enzyme that hydrolyzes inositol triphosphate in astrocytes blocked calcium transients and reduced the growth of dendrites and axons by $60-70 \%$. Wild-type and mutant forms of the enzyme differentially affected spontaneous and evoked calcium oscillations, while the growth-promoting activity of astrocytes required spontaneous transients. The decreased neurite growth on astrocytes with deficient calcium signaling was caused by lower levels of the cell adhesion molecule $N$-cadherin, which is well-known to promote neurite growth.

A new mechanism by which glial cells stimulate neurite outgrowth has recently been discovered in olfactory ensheathing glia [64]. This special type of glial cell in the olfactory bulb guides and promotes the growth of axons from olfactory receptor neurons, which are generated throughout life and integrate into the olfactory circuit [65]. Olfactory ensheathing glia prepared from embryonic mice released osteonectin/secreted protein acidic rich in cysteine (Sparc). Sparc in turn enables Schwann cells to promote neurite outgrowth from explants of dorsal root ganglia from mouse embryos [64]. This effect required transforming growth factor beta $(\operatorname{Tgf} \beta)$ and was promoted by laminin [64]. These data show that neurite outgrowth requires the cooperative actions of multiple signals, whose cellular sources and targets remain to be clarified.

\section{Why should glia influence synapse development? It's the timing, stupid!}

The idea that synaptogenesis is controlled by glial cells derives from a temporal correlation between synapse formation and astrocyte development in the rodent CNS [66], where the large majority of synaptic connections are generated during a protracted phase that spans from the first to the third postnatal week. Curiously, this happens after the formation of astrocytes [67], suggesting that bulk synaptogenesis requires glia. Fluorescent labeling of individual astrocytes by dye injection plus immunohistochemical staining revealed drastic morphological changes in astrocytes at the time of postnatal synapse development, which supports speculations about their role in synaptogenesis [68]. It should be noted that the temporal coincidence of synapse development and astrocyte differentiation applies mainly to glutamatergic connections. $\gamma$-Aminobutyric acid (GABA)-ergic neurons establish a functional network in the embryonic brain well before astrocytes are generated $[13,69]$, indicating glia-independent formation of GABAergic contacts.

\section{Can neurons form contacts autonomously? Models matter!}

The requirement of glial cells for synaptogenesis has been studied mainly in culture preparations: glia-free cultures allow to address a key question, namely whether neurons can form synapses without glia. Such cultures can be obtained by three methods: (1) neuronal cultures can be prepared from rodent brains on embryonic day 15-17, before glial cells are generated; (2) neurons can be prepared from postnatal brains after active separation from glia by immunoisolation [70-72] or by fluorescence-activated cell sorting [73-75]; (3) neurons can be generated from stem cells by promoting their neuronal differentiation [58, 76, 77]. These methods reach purities of up to $99.5 \%$ and thereby establish virtually glia-free conditions. Studies on such preparations have revealed that there is no absolute requirement for glia: some neurons can make connections (Fig. 2a), whereas others cannot (Fig. 2b). RGCs, motoneurons, and PCs immunoisolated from postnatal rodents formed only very few synapses under glia-free conditions [71, 78, 79] (Buard and Pfrieger, unpublished observation). Synapses among these neurons may be regarded as artificial, as they form their connections in vivo with partners that were not present in the cultures. However, few synapses were also observed in glia-free cultures of subplate neurons from embryonic rats or mice, which normally form synapses among each other [80]. On the other hand, strong glutamatergic and GABAergic synaptic activity was found in serum- and glia-free cultures of neurons from superior cervical ganglia of newborn rats [81], from spinal cords of embryonic mice [82], and from hippocampi and cerebella of postnatal mice [72]. In some of these preparations, a glial influence due to presence a few glial cells cannot be excluded. Nonetheless, the data suggest that the requirement for glia varies with the neuronal cell type: long-projecting neurons may need glia to form or receive synapses, whereas locally connecting cells may not.

Interestingly, the results from two studies on distinct culture preparations suggest that the competence of neurons to form and to receive synapses develop independently, although the reports disagree on the sequence of events. RGCs immunoisolated from embryonic rats could form, but not receive synapses, and the latter ability required contact with astrocytes [83]. A reversed sequence was observed in neurons that were generated by genetic re-programming of glial fibrillary acid protein-positive cells from the cerebellar cortex of postnatal mice. These neurons were able to receive glutamatergic inputs but were unable to form presynaptic contacts [77]. 


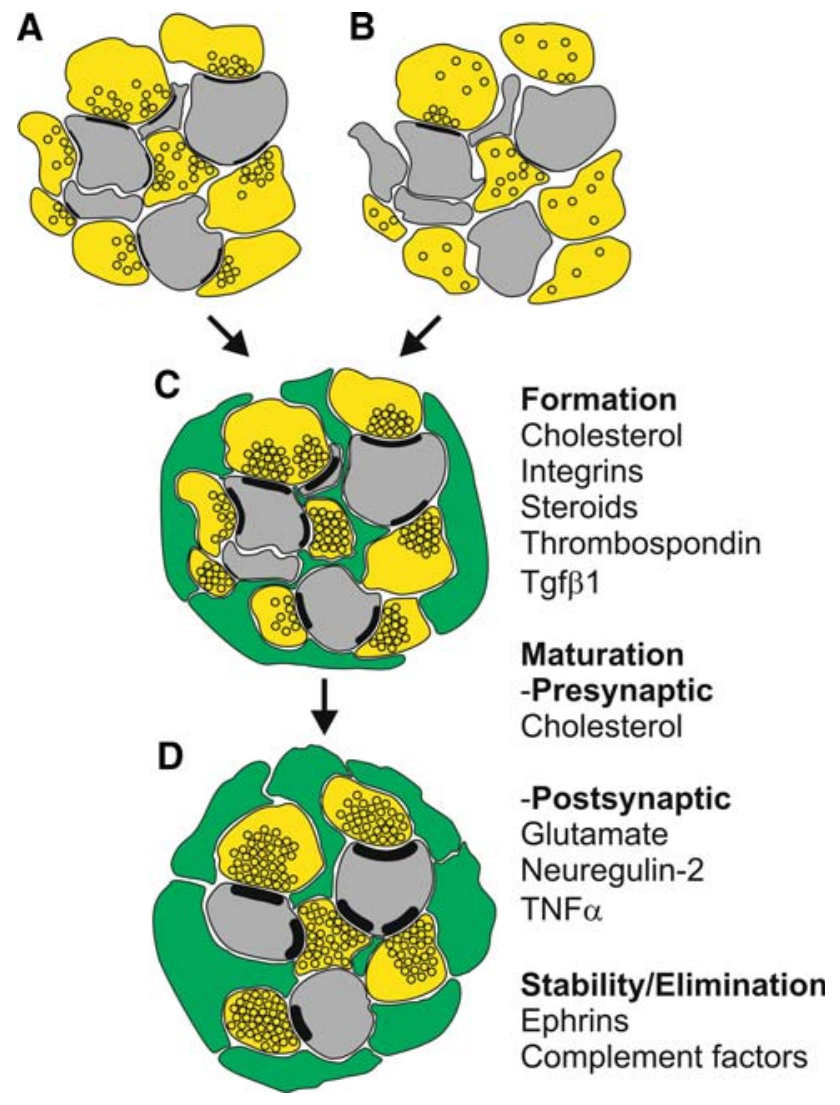

Fig. 2 Influences of glia on synapse development. Diagram illustrating the different effects of glia (green) on the development of synaptic connections between pre- (yellow) and postsynaptic (grey) partner neurons. Some neurons form synapses in the absence of glial cells (a), whereas others do not (b). Glia-derived factors promote synapse formation in the latter and enhance the pre- and postsynaptic efficacy of connections (c). In addition, they contribute to the stabilization or destruction of synaptic connections (d). Molecules implicated in gliasynapse interactions during development are indicated

The discrepancy may be due to the different neuronal cell types or culture preparations.

The most important question, namely, whether synaptogenesis requires glial cells in living animals, can only be addressed in invertebrate and vertebrate species, but not in mammals. Genetic ablation of astrocytes in developing and adult mice causes massive damage to neurons [84, 85], which precludes conclusions on their relevance for synaptogenesis. In $C$. elegans, whose cells are fully inventoried, four of its 50 glia-like cells, the so-called CEPsh glia, are in contact with dendrites of sensory neurons and with synaptic connections in the nerve ring [40]. Their ablation by optical and genetic methods does not impair the survival of associated sensory neurons, but it does perturb their morphology [62] and impair chemotactic behavior [86]. However, it remains unclear whether synapse formation is affected. Selective ablation of PSCs in developing and adult frogs has been accomplished by a PSC-specific antibody combined with complement-mediated cell lysis. These experiments revealed that PSCs are required for the formation and growth of neuromuscular junctions (NMJs) in developing frogs in vivo [87].

\section{Do glial cells promote the formation of synaptic contacts? Yes, but be aware!}

Whether or not glial cells are required for the establishment of synaptic contacts, there is evidence that they increase their formation based on electron microscopic and immunocytochemical studies of different primary culture preparations (Fig. 2c). These include cocultures of frog spinal cord neurons and myocytes [88, 89], cultured rat and mouse RGCs [72, 78, 79, 90], PCs (Buard and Pfrieger, unpublished observation), motoneurons [71, 89], neurons derived from human embryonic stem cells [58], as well as cortical [80, 91] and hippocampal neurons [92, 93] from embryonic rats, where glia also increased the frequency of action potential-independent (miniature) postsynaptic currents [80, 91, 94]. All of the cited studies have focused on excitatory synapses. Astrocytes also enhanced the number of inhibitory connections among cultured hippocampal neurons from embryonic rats, an effect that required brainderived neurotrophic factor signaling in neurons [95]. On the other hand, Steinmetz and colleagues [72] did not observe glial effects on inhibitory synapses in hippocampal neurons immunoisolated from postnatal mice. The diverging results may be due to age- and preparationdependent differences.

A caveat in these studies is that the observed increase in synapse numbers may be secondary to glial promotion of neuronal survival and/or growth. Glia-induced dendritogenesis, which facilitates synapse formation, was detected in stem cell-derived neurons [58] and in RGCs [59]. A gliainduced increase in the number of surviving neurons can explain the enhanced level of synaptic activity [93], whereas other studies have excluded this possibility [71, 72, 80, 90, 95].

Remarkably, glial cells can also have the opposite effect and impede synapse formation, for example by preventing physical contact between neurons. In vivo studies showed that decreased glial ensheathment of cerebellar PCs enhances the number of synaptic inputs [96, 97]. Alternatively, astrocytes may suppress synaptogenesis by secreted signals: fibroblast growth factor 2 , which is produced by astrocytes, lowers the number of synapses in cultured mesencephalic neurons from neonatal rats [98], but the mechanism remains unclear. 


\section{Do glial cells promote synapse maturation? Glia foster fitness}

There is evidence that glial cells promote the maturation of synapses, when the connections attain their characteristic transmission properties (Fig. 2c). In single-cell microcultures of neurons from rat superior cervical ganglia, Schwann cells were dispensable for the formation of cholinergic connections, but they did enhance the frequency of action potential-independent release and pairedpulse depression [81]. Both changes indicate a glial enhancement of release efficacy, which has also been observed in cultured RGCs [59, 78, 99]. Glial signals also enhanced the size of miniature excitatory postsynaptic currents in primary cultures of immunoisolated hippocampal neurons [72], cortical subplate neurons [80], RGCs [72, 78, 79], and spinal cord motoneurons [71]. This latter effect points to an enhancement of postsynaptic glutamate sensitivity, although presynaptic causes, such as an increased vesicular glutamate content, cannot be excluded. Notably, in dissociated and organotypic cultures of hippocampal neurons, glia-derived tumor necrosis factor alpha regulates activity-dependent changes in postsynaptic receptor density [100].

Transcript profiling of cultured RGCs by oligonucleotide microarrays revealed that glial signals enhance mRNA levels of glutamate receptor subunits and of components that regulate their clustering and stability [101]. Similar changes were observed in a microarray analysis of cortical subplate neurons [80]. Further evidence that glial signals promote postsynaptic maturation comes from studies on NMJs. Neuregulin 2 is produced by PSCs covering NMJs of adult rats and stimulates the transcription of acetylcholine receptors (AChR) by activating the ErbB4 receptor in a muscle cell line $[102,103]$. Whether NMJ formation per se depends on the subsynaptic transcription of AChRs is unclear [104]. In Drosophila, elimination of a cysteine/ glutamate transporter, which is expressed in NMJ-associated glial cells, reduces the extracellular glutamate level by half and increases the number of glutamate receptors in NMJs by two- to threefold [105], indicating that gliacontrolled glutamate levels regulate the postsynaptic sensitivity of NMJs.

\section{Glia-synapse communication: mind the signals!}

A key to understand how glial cells influence synapse development is to identify the molecular basis of this process. Within the last years, there has been some progress in this area, namely the identification of synaptogenic components from glia.
Previous studies showed that Schwann cells promote the formation of NMJs in vitro [88]. A candidate approach recently identified $\operatorname{Tgf} \beta 1$ as one of the factors involved in this process [89]. The authors further reported that $\operatorname{Tgf} \beta 1$ mediates the previously reported increase in neuronal agrin levels [88] which, in turn, control AChR expression and clustering. These results substantiate the glial control of AChR levels in myotubes. However, $\operatorname{Tgf} \beta 1$ did not mimic the potentiation of spontaneous transmitter release from motoneuron terminals that was observed after acute application of Schwann cell-conditioned medium [106].

In the CNS, a few secreted glial factors that promote synapse formation have been uncovered. Thrombospondin was identified as an astrocyte-derived matrix component that promotes the formation of ultrastructurally normal, but postsynaptically silent synapses in cultured RGCs. Transgenic mice lacking thrombospondins showed a reduced density of immunohistochemically identified synapses in the cortex [99]. Another glial factor that contributes to this process is cholesterol [107]. Cholesterol promotes several aspects of synaptogenesis in RGCs. It enhances the efficacy of presynaptic transmitter release, enables dendrite differentiation and promotes the redistribution of glutamate receptors. Externally supplied cholesterol also sustained continuous synapse development and the stability of evoked release [59]. Neurons may require external cholesterol as building material for dendrites and synapses because they cannot produce sufficient amounts on their own [108]. Cholesterol can also influence signaling pathways-albeit indirectly. Our data suggest that cholesterol treatment modifies the membrane structure of cultured RGCs (Thiebaut et al., unpublished observation), which may affect the properties of membrane-resident signaling components. A synaptogenic effect of neurosteroids, which are produced from cholesterol, was excluded in the case of RGCs [59]. However, in primary cultures of cortical neurons, estradiol mimics the glia-induced increase in synapse number and function [91]. Moreover, estradiol controls the density of synapses and the level of synaptophysin in hippocampal slice cultures [109], although the cellular source of the steroid remains unknown. Progesterone enhances synapse formation in cultured hippocampal neurons. This effect required the presence of astrocytes and was possibly mediated by an increase in the glial production of agrin [92]. Cholesterol, estrogen, and creatine enhance the number and activity of synapses in cultured hippocampal neurons [110], but it remains unclear which factor induced the effect. Contact-dependent signals may also promote synapse development. In hippocampal microisland cultures, local contact with an astrocyte increases the number of synapses across the entire neuron, and integrins and protein kinase $\mathrm{C}$ are involved in this process [111]. As 
described above, RGCs from E17 rats can only receive synaptic inputs when in contact to astrocytes, and this effect may involve changes in the subcellular distribution of neurexins [83]. In both cases, however, the astrocytic signals that initiate these changes remain unknown.

The identification of glial signals that influence synaptogenesis by biochemical purification and candidate guesswork is laborious and not always crowned by success. Fortunately, new techniques have emerged within the last years that complement these traditional approaches. For example, transcriptional profiling of neurons cultured with or without glial factors can provide a global view on the influence of glia on neurons and uncover unexpected pathways. Three recent reports have proven the validity of this approach [80, 101, 112]. Two studies on cultured RGCs revealed a glia-induced upregulation of components that had not yet been discussed in a neuronal context. This included a complement factor that contributes to synapse elimination (see below) [112] and matrix gla protein (Mgp), a component of the extracellular matrix, which regulates calcification in the body [101]. Interestingly, a recent study showed that Mgp modifies neuronal signaling by bone morphogenetic proteins, which belong to the Tgf family [113].

\section{Should it stay or should it go? Glia live and let die!}

Like many partnerships, synaptic connections have a limited life-time. Their turnover is particularly high during development, when neurons form promiscuous connections, and dump them subsequently. In adult mice, synapses appear to be more stable and last for many months, as shown by in vivo two-photon imaging of fluorescently labeled neurons [114]. On the other hand, synapse loss may spearhead the cascade of pathological changes in neurodegenerative diseases $[115,116]$.

There is now evidence that glial cells enhance the stability of synaptic connections (Fig. 2d): simultaneous time-lapse imaging of fluorescently labeled astrocytes and dendritic spines in organotypic hippocampal cultures revealed that contact to astrocytes enhances the life-time of dendritic protrusions and promotes their conversion to spines. This effect was possibly mediated by ephrin-A3/ EphA4 signaling [117]. Ablation of PSCs in adult frogs in vivo caused the loss of NMJs [87], indicating that their maintenance depends on the glial sheath. There are also indications for the opposite, namely, that glial cells promote the death of synapses. A striking mechanism was uncovered by a study on immunoisolated RGCs [112]. Coculture with glial cells strongly enhanced the neuronal level of $\mathrm{C} 1 \mathrm{q}$, a component of the complement cascade, which was present at synapses. Mice lacking C1q showed defects in the eye-specific segregation of synaptic inputs to the lateral geniculate nucleus [112]. These observations suggest that astrocytes command the onset and extent of synapse execution by as yet unknown signals.

Synapse destruction can involve the removal of axonal branches that form obsolete connections. In the peripheral nervous system, motoneurons form supernumerary NMJs, most of which are destroyed postnatally [118]. Repeated imaging of NMJs in living transgenic mice combined with electron microscopy revealed that axon remnants, the socalled axosomes, end up in PSCs [119]. Moreover, the elimination of unwanted NMJs and climbing fiber inputs to cerebellar PCs was accompanied by enhanced lysosomal activity in glial cells [120]. Whether glial cells play an active or passive role in this process remains unclear.

Direct evidence for an active glial contribution to axon-and thereby synapse-removal comes from studies on the olfactory system of flies, which undergoes substantial remodeling during metamorphosis [121]. Selective labeling of neurons and glial cells in the mushroom body and genetic disturbance of glial membrane function revealed an active role of glial cells in the pruning of axons [122-124].

\section{What's in store for astrocyte-synapse interactions? Don't miss the buzz!}

The research progress documented in this review is to a great part driven by technical advances, which will continue to propel the field. Three "techno-tracks" seem to be of particular importance.

First, advanced genetic and proteomic approaches will divulge the molecular setup of astrocytes. An important first step has been the transcriptional profiling of cultured and acutely isolated astrocytes [125-128], retinal Müller cells [129], and Schwann cells [130] of developing and adult rodents. Moreover, the proteome and secretome of cultured astrocytes have been inventoried [64, 131-133]. Evidently, the molecular signature of isolated or cultured cells may not reflect the situation in vivo. This caveat can be overcome by exciting new approaches to transcriptional profiling in vivo, based on new molecular baits for transcription complexes [134] and on the bioinformatic analysis of coexpression [135]. Together, these techniques should provide a comprehensive molecular definition of astrocytes, which - up to now-has been based on very few markers. Ultimately, such new approaches may lead to a molecular classification of astrocytes that is of a similar complexity as that for neurons.

Second, glial cells and their interactions with synapses can now be visualized in a much more refined and dynamic manner than ever before thanks to technical advances in 
cell labeling and microscopy. First, astrocytes can be visualized in vivo or in situ by fluorescent molecules. Dyes can be applied by micro-iontophoretic injection in lightly fixed tissue [136] or by topical application to the brain surface of living animals [137]. These methods, in combination with confocal or two-photon microscopy, have brought unprecedented insight in the morphology and spatial arrangement of astrocytes under normal and pathological conditions [136, 138] and have allowed, for example, to separate astrocytic from neuronal calcium signals [137]. An alternative method that circumvents dyerelated problems is based on the glia-specific expression of fluorescent proteins in transgenic animals. Time-lapse imaging of fluorescently labeled neurons and astrocytes in intact preparations has revealed a high motility of glial filopodia [139, 140] and their dynamic interactions with dendritic spines [97, 117, 141, 142]. Astrocytes interact with synapses via extremely delicate processes in the micrometer range, whose visualization evades conventional light microscopy. These key structural domains and their dynamics can be reconstructed by serial section electron microscopy [143] and advanced 3D computer electron tomography [144]. More insight at the ultrastructural level will probably come from new light [145] and electron microscopy techniques [146, 147].

Third, new animal models allow to test the functional relevance of glial cells for synapse development and function in vivo. Several transgenic mouse lines enable astroglia-specific somatic mutagenesis based on the Cre/ loxP system and different astrocyte-specific promoters contained in short transgenesis vectors (hGfap: [148, 149]), bacterial artificial chromosomes (see [150] for Glast and Cx30; [151] for Gfap; [129] for Pdgfra; [152] for Blbp) or genomic DNA ([153] for Glast). Moreover, transgenic mice have been generated to overexpress specific proteins in astrocytes [152, 154] and to reversibly target Schwann cells [54] and astrocytes [155, 156] by the Tet-on/-off system. Alternatively, virus-based transfection of astrocytes in vivo is now possible by a lentiviral construct that achieves preferential targeting of astrocytes [157].

Finally, visualization of glial cells can be combined with functional manipulation in genetically modified worms and flies, where the characterization of glial cells and their interactions with synapses are progressing quickly [40, 158]. These invertebrate models will certainly continue to provide important insights in glia-synapse interactions and to inspire further research on the situation in vertebrates.

\section{Summary and outlook}

Three lessons can be learnt from this review. First, the plot thickens: neurons require help from their glial friends to find their match, to form strong, enduring connections, and to eliminate obsolete liaisons. Second, the chances to understand these interactions are increasing thanks to relentless technical advances in areas such as molecular characterization, visualization, and functional interference in glial cells. Finally, a sine qua non for further progress remains the identification of signaling pathways, as this is vital to determine the relevance of glia for the development and maintenance of synaptic connections and to explore their potential to repair brain damage. Whatever is in store, the times are exciting for those interested in glia-synapse interactions.

Acknowledgments The author gratefully acknowledges support by Agence Francaise Contres les Myopathies, Agence Nationale de la Recherche, Ara Parseghian Medical Research Foundation, Centre National de la Recherche Scientifique, Deutsche Forschungsgemeinschaft, ELTEM, European Commission Coordination Action ENINET (contract number LSHM-CT-2005-19063), Fondation NRJInstitut de France, Fondation pour la Recherche Medicale, MaxPlanck Gesellschaft, Merck-Serono, Miltenyi Biotech, Neurex, Region Alsace, Retina France, and Sanofi-Aventis.

Open Access This article is distributed under the terms of the Creative Commons Attribution Noncommercial License which permits any noncommercial use, distribution, and reproduction in any medium, provided the original author(s) and source are credited.

\section{References}

1. Saviane C, Silver RA (2006) Fast vesicle reloading and a large pool sustain high bandwidth transmission at a central synapse. Nature 439:983-987

2. Waites CL, Craig AM, Garner CC (2005) Mechanisms of vertebrate synaptogenesis. Annu Rev Neurosci 28:251-274

3. Akins MR, Biederer T (2006) Cell-cell interactions in synaptogenesis. Curr Opin Neurobiol 16:83-89

4. Craig AM, Graf ER, Linhoff MW (2006) How to build a central synapse: clues from cell culture. Trends Neurosci 29:8-20

5. Fox MA, Umemori H (2006) Seeking long-term relationship: axon and target communicate to organize synaptic differentiation. J Neurochem 97:1215-1231

6. Gerrow K, El Husseini A (2006) Cell adhesion molecules at the synapse. Front Biosci 11:2400-2419

7. Paukert M, Bergles DE (2006) Synaptic communication between neurons and NG2+ cells. Curr Opin Neurobiol 16:515-521

8. Prokop A, Meinertzhagen IA (2006) Development and structure of synaptic contacts in Drosophila. Semin Cell Dev Biol 17:20 30

9. McAllister AK (2007) Dynamic aspects of CNS synapse formation. Annu Rev Neurosci 30:425-450

10. Polleux F, Ince-Dunn G, Ghosh A (2007) Transcriptional regulation of vertebrate axon guidance and synapse formation. Nat Rev Neurosci 8:331-340

11. Arikkath J, Reichardt LF (2008) Cadherins and catenins at synapses: roles in synaptogenesis and synaptic plasticity. Trends Neurosci 31:487-494

12. Greer PL, Greenberg ME (2008) From synapse to nucleus: calcium-dependent gene transcription in the control of synapse development and function. Neuron 59:846-860 
13. Huang ZJ, Scheiffele P (2008) GABA and neuroligin signaling: linking synaptic activity and adhesion in inhibitory synapse development. Curr Opin Neurobiol 18:77-83

14. Margeta MA, Shen K, Grill B (2008) Building a synapse: lessons on synaptic specificity and presynaptic assembly from the nematode C. elegans. Curr Opin Neurobiol 18:69-76

15. Slezak M, Pfrieger FW (2003) New roles for astrocytes: regulation of CNS synaptogenesis. Trends Neurosci 26:531-535

16. Ullian EM, Christopherson KS, Barres BA (2004) Role for glia in synaptogenesis. GLIA 47:209-216

17. Virchow R (1856) Gesammelte Abhandlungen zur wissenschaftlichen Medizin. Meidinger Sohn \& Co, Frankfurt am Main

18. Kettenmann H, Ransom BR (2004) The concept of neuroglia: a historical perspective. In: Kettenmann H, Ransom BR (eds) Neuroglia. Oxford University Press, New York, pp 1-16

19. Oberheim NA, Wang X, Goldman S, Nedergaard M (2006) Astrocytic complexity distinguishes the human brain. Trends Neurosci 29:547-553

20. Barres BA (2008) The mystery and magic of glia: a perspective on their roles in health and disease. Neuron 60:430-440

21. Seth P, Koul N (2008) Astrocyte, the star avatar: redefined. J Biosci 33:405-421

22. Kim SU, de Vellis $\mathbf{J}$ (2005) Microglia in health and disease. $\mathbf{J}$ Neurosci Res 81:302-313

23. Garden GA, Moller T (2006) Microglia biology in health and disease. J. Neuroimmune Pharmacol 1:127-137

24. Hanisch UK, Kettenmann H (2007) Microglia: active sensor and versatile effector cells in the normal and pathologic brain. Nat Neurosci 10:1387-1394

25. Kettenmann H, Ransom BR (2004) Neuroglia. Oxford University Press, New York

26. McDermott KW, Barry DS, McMahon SS (2005) Role of radial glia in cytogenesis, patterning and boundary formation in the developing spinal cord. J Anat 207:241-250

27. Bringmann A, Pannicke T, Grosche J, Francke M, Wiedemann P, Skatchkov SN, Osborne NN, Reichenbach A (2006) Muller cells in the healthy and diseased retina. Prog Retin Eye Res 25:397-424

28. Spacek J (1971) Three-dimensional reconstruction of astroglia and oligodendroglia cells. Z Zellforsch Mikrosk Anat 112:430-442

29. Grosche J, Matyash V, Moller T, Verkhratsky A, Reichenbach A, Kettenmann H (1999) Microdomains for neuron-glia interaction: parallel fiber signaling to Bergmann glial cells. Nat Neurosci 2:139-143

30. Witcher MR, Kirov SA, Harris KM (2007) Plasticity of perisynaptic astroglia during synaptogenesis in the mature rat hippocampus. GLIA 55:13-23

31. Araque A, Parpura V, Sanzgiri RP, Haydon PG (1999) Tripartite synapses: glia, the unacknowledged partner. Trends Neurosci 22:208-215

32. Perea G, Araque A (2007) Astrocytes potentiate transmitter release at single hippocampal synapses. Science 317:1083-1086

33. Suh J, Jackson FR (2007) Drosophila ebony activity is required in glia for the circadian regulation of locomotor activity. Neuron 55:435-447

34. Grosjean Y, Grillet M, Augustin H, Ferveur JF, Featherstone DE (2008) A glial amino-acid transporter controls synapse strength and courtship in Drosophila. Nat Neurosci 11:54-61

35. Fields RD, Burnstock G (2006) Purinergic signalling in neuronglia interactions. Nat Rev Neurosci 7:423-436

36. Freeman MR (2006) Sculpting the nervous system: glial control of neuronal development. Curr Opin Neurobiol 16:119-125

37. Haydon PG, Carmignoto G (2006) Astrocyte control of synaptic transmission and neurovascular coupling. Physiol Rev 86:1009_ 1031
38. Martineau M, Baux G, Mothet JP (2006) D-serine signalling in the brain: friend and foe. Trends Neurosci 29:481-491

39. Rousse I, Robitaille R (2006) Calcium signaling in Schwann cells at synaptic and extra-synaptic sites: active glial modulation of neuronal activity. GLIA 54:691-699

40. Shaham S (2006) Glia-neuron interactions in the nervous system of Caenorhabditis elegans. Curr Opin Neurobiol 16:522-528

41. Verkhratsky A (2006) Patching the glia reveals the functional organisation of the brain. Pflugers Arch 453:411-420

42. Feng Z, Ko CP (2007) Neuronal glia interactions at the vertebrate neuromuscular junction. Curr Opin Pharmacol $7: 316-324$

43. Iadecola C, Nedergaard M (2007) Glial regulation of the cerebral microvasculature. Nat Neurosci 10:1369-1376

44. Murai KK, Van Meyel DJ (2007) Neuron glial communication at synapses: insights from vertebrates and invertebrates. Neuroscientist 13:657-666

45. Ni Y, Malarkey EB, Parpura V (2007) Vesicular release of glutamate mediates bidirectional signaling between astrocytes and neurons. J Neurochem 103:1273-1284

46. Agulhon C, Petravicz J, McMullen AB, Sweger EJ, Minton SK, Taves SR, Casper KB, Fiacco TA, McCarthy KD (2008) What is the role of astrocyte calcium in neurophysiology? Neuron 59:932-946

47. De Keyser J, Mostert JP, Koch MW (2008) Dysfunctional astrocytes as key players in the pathogenesis of central nervous system disorders. J Neurol Sci 267:3-16

48. Garcia-Segura LM, Lorenz B, DonCarlos LL (2008) The role of glia in the hypothalamus: implications for gonadal steroid feedback and reproductive neuroendocrine output. Reproduction 135:419-429

49. Santello M, Volterra A (2008) Synaptic modulation by astrocytes via $\mathrm{Ca}(2+)$-dependent glutamate release. Neuroscience 158:253-259

50. Theodosis DT, Poulain DA, Oliet SH (2008) Activity-dependent structural and functional plasticity of astrocyte-neuron interactions. Physiol Rev 88:983-1008

51. Powell SK, Kleinman HK (1997) Neuronal laminins and their cellular receptors. Int J Biochem Cell Biol 29:401-414

52. Araujo SJ, Tear G (2003) Axon guidance mechanisms and molecules: lessons from invertebrates. Nat Rev Neurosci 4:910 922

53. Williams SE, Mason CA, Herrera E (2004) The optic chiasm as a midline choice point. Curr Opin Neurobiol 14:51-60

54. Hayworth CR, Moody SE, Chodosh LA, Krieg P, Rimer M, Thompson WJ (2006) Induction of neuregulin signaling in mouse Schwann cells in vivo mimics responses to denervation. J Neurosci 26:6873-6884

55. Ango F, Wu C, Van der Want JJ, Wu P, Schachner M, Huang ZJ (2008) Bergmann glia and the recognition molecule CHL1 organize GABAergic axons and direct innervation of Purkinje cell dendrites. PLoS Biol 6:e103

56. Lordkipanidze T, Dunaevsky A (2005) Purkinje cell dendrites grow in alignment with Bergmann glia. GLIA 51:229-234

57. Yamada K, Fukaya M, Shibata T, Kurihara H, Tanaka K, Inoue Y, Watanabe M (2000) Dynamic transformation of Bergmann glial fibers proceeds in correlation with dendritic outgrowth and synapse formation of cerebellar Purkinje cells. J Comp Neurol 418:106-120

58. Johnson MA, Weick JP, Pearce RA, Zhang SC (2007) Functional neural development from human embryonic stem cells: accelerated synaptic activity via astrocyte coculture. J Neurosci 27:3069-3077

59. Goritz C, Mauch DH, Pfrieger FW (2005) Multiple mechanisms mediate cholesterol-induced synaptogenesis in a CNS neuron. Mol Cell Neurosci 29:190-201 
60. Yamamoto M, Ueda R, Takahashi K, Saigo K, Uemura T (2006) Control of axonal sprouting and dendrite branching by the $\mathrm{Nrg}-$ Ank complex at the neuron-glia interface. Curr Biol 16:16781683

61. Colon-Ramos DA, Margeta MA, Shen K (2007) Glia promote local synaptogenesis through UNC-6 (netrin) signaling in $C$. elegans. Science 318:103-106

62. Yoshimura S, Murray JI, Lu Y, Waterston RH, Shaham S (2008) mls-2 and vab-3 Control glia development, hlh-17/Olig expression and glia-dependent neurite extension in C. elegans. Development 135:2263-2275

63. Kanemaru K, Okubo Y, Hirose K, Iino M (2007) Regulation of neurite growth by spontaneous $\mathrm{Ca} 2+$ oscillations in astrocytes. $\mathrm{J}$ Neurosci 27:8957-8966

64. Au E, Richter MW, Vincent AJ, Tetzlaff W, Aebersold R, Sage EH, Roskams AJ (2007) SPARC from olfactory ensheathing cells stimulates Schwann cells to promote neurite outgrowth and enhances spinal cord repair. J Neurosci 27:7208-7221

65. Ramon-Cueto A, Avila J (1998) Olfactory ensheathing glia: properties and function. Brain Res Bull 46:175-187

66. Pfrieger FW, Barres BA (1996) New views on synapse-glia interactions. Curr Opin Neurobiol 6:615-621

67. Miller FD, Gauthier AS (2007) Timing is everything: making neurons versus glia in the developing cortex. Neuron 54:357369

68. Bushong EA, Martone ME, Ellisman MH (2004) Maturation of astrocyte morphology and the establishment of astrocyte domains during postnatal hippocampal development. Int J Dev Neurosci 22:73-86

69. Ben-Ari Y (2002) Excitatory actions of gaba during development: the nature of the nurture. Nat Rev Neurosci 3:728-739

70. Barres BA, Silverstein BE, Corey DP, Chun LLY (1988) Immunological, morphological, and electrophysiological variation among retinal ganglion cells purified by panning. Neuron $1: 791-803$

71. Ullian EM, Harris BT, Wu A, Chan JR, Barres BA (2004) Schwann cells and astrocytes induce synapse formation by spinal motor neurons in culture. Mol Cell Neurosci 25:241-251

72. Steinmetz CC, Buard I, Claudepierre T, Nagler K, Pfrieger FW (2006) Regional variations in the glial influence on synapse development in the mouse CNS. J Physiol 577:249-261

73. Calof AL, Reichardt LF (1984) Motoneurons purified by cell sorting respond to two distinct activities in myotube-conditioned medium. Dev Biol 106:194-210

74. Tomomura M, Rice DS, Morgan JI, Yuzaki M (2001) Purification of Purkinje cells by fluorescence-activated cell sorting from transgenic mice that express green fluorescent protein. Eur J Neurosci 14:57-63

75. Pennartz S, Belvindrah R, Tomiuk S, Zimmer C, Hofmann K, Conradt M, Bosio A, Cremer H (2004) Purification of neuronal precursors from the adult mouse brain: comprehensive gene expression analysis provides new insights into the control of cell migration, differentiation, and homeostasis. Mol Cell Neurosci 25:692-706

76. Jungling K, Nagler K, Pfrieger FW, Gottmann K (2003) Purification of embryonic stem cell-derived neurons by immunoisolation. FASEB J 17:2100-2102

77. Berninger B, Costa MR, Koch U, Schroeder T, Sutor B, Grothe B, Gotz M (2007) Functional properties of neurons derived from in vitro reprogrammed postnatal astroglia. J Neurosci 27:86548664

78. Nagler K, Mauch DH, Pfrieger FW (2001) Glia-derived signals induce synapse formation in neurons of the rat central nervous system. J Physiol 533:665-679

79. Ullian EM, Sapperstein SK, Christopherson KS, Barres BA (2001) Control of synapse number by glia. Science 291:657-661
80. McKellar CE, Shatz CJ (2008) Synaptogenesis in purified cortical subplate neurons. Cereb Cortex. doi: 10.1093/cercor/ bhn194

81. Perez-Gonzalez AP, Albrecht D, Blasi J, Llobet A (2008) Schwann cells modulate short-term plasticity of cholinergic autaptic synapses. J Physiol 586:4675-4691

82. Cuevas ME, Carrasco MA, Fuentes Y, Castro P, Nualart F, Roa J, Aguayo LG (2005) The presence of glia stimulates the appearance of glycinergic synaptic transmission in spinal cord neurons. Mol Cell Neurosci 28:770-778

83. Barker AJ, Koch SM, Reed J, Barres BA, Ullian EM (2008) Developmental control of synaptic receptivity. J Neurosci 28:8150-8160

84. McCall MA, Gregg RG, Behringer RR, Brenner M, Delaney CL, Galbreath EJ, Zhang CL, Pearce RA, Chiu SY, Messing A (1996) Targeted deletion in astrocyte intermediate filament (Gfap) alters neuronal physiology. Proc Natl Acad Sci USA 93:6361-6366

85. Cui W, Allen ND, Skynner M, Gusterson B, Clark AJ (2001) Inducible ablation of astrocytes shows that these cells are required for neuronal survival in the adult brain. GLIA 34:272-282

86. Bacaj T, Tevlin M, Lu Y, Shaham S (2008) Glia are essential for sensory organ function in C. elegans. Science 322:744-747

87. Reddy LV, Koirala S, Sugiura Y, Herrera AA, Ko CP (2003) Glial cells maintain synaptic structure and function and promote development of the neuromuscular junction in vivo. Neuron 40:563-580

88. Peng HB, Yang JF, Dai Z, Lee CW, Hung HW, Feng ZH, Ko CP (2003) Differential effects of neurotrophins and schwann cellderived signals on neuronal survival/growth and synaptogenesis. J Neurosci 23:5050-5060

89. Feng Z, Ko CP (2008) Schwann cells promote synaptogenesis at the neuromuscular junction via transforming growth factorbeta1. J Neurosci 28:9599-9609

90. Pfrieger FW, Barres BA (1997) Synaptic efficacy enhanced by glial cells in vitro. Science 277:1684-1687

91. Hu R, Cai WQ, Wu XG, Yang Z (2007) Astrocyte-derived estrogen enhances synapse formation and synaptic transmission between cultured neonatal rat cortical neurons. Neuroscience 144:1229-1240

92. Tournell CE, Bergstrom RA, Ferreira A (2006) Progesteroneinduced agrin expression in astrocytes modulates glia-neuron interactions leading to synapse formation. Neuroscience 141:1327-1338

93. Boehler MD, Wheeler BC, Brewer GJ (2007) Added astroglia promote greater synapse density and higher activity in neuronal networks. Neuron Glia Biol 3:127-140

94. Yang Y, Ge W, Chen Y, Zhang Z, Shen W, Wu C, Poo M, Duan S (2003) Contribution of astrocytes to hippocampal long-term potentiation through release of D-serine. Proc Natl Acad Sci USA 100:15194-15199

95. Elmariah SB, Oh EJ, Hughes EG, Balice-Gordon RJ (2005) Astrocytes regulate inhibitory synapse formation via Trk-mediated modulation of postsynaptic GABAA receptors. J Neurosci 25:3638-3650

96. Iino M, Goto K, Kakegawa W, Okado H, Sudo M, Ishiuchi S, Miwa A, Takayasu Y, Saito I, Tsuzuki K, Ozawa S (2001) Gliasynapse interaction through $\mathrm{Ca} 2+$-permeable AMPA receptors in Bergmann glia. Science 292:926-929

97. Lippman JJ, Lordkipanidze T, Buell ME, Yoon SO, Dunaevsky A (2008) Morphogenesis and regulation of Bergmann glial processes during Purkinje cell dendritic spine ensheathment and synaptogenesis. GLIA 56:1463-1477

98. Forget C, Stewart J, Trudeau LE (2006) Impact of basic FGF expression in astrocytes on dopamine neuron synaptic function and development. Eur J Neurosci 23:608-616 
99. Christopherson KS, Ullian EM, Stokes CC, Mullowney CE, Hell JW, Agah A, Lawler J, Mosher DF, Bornstein P, Barres BA (2005) Thrombospondins are astrocyte-secreted proteins that promote CNS synaptogenesis. Cell 120:421-433

100. Stellwagen D, Malenka RC (2006) Synaptic scaling mediated by glial TNF-alpha. Nature 440:1054-1059

101. Goritz C, Thiebaut R, Tessier LH, Nieweg K, Moehle C, Buard I, Dupont JL, Schurgers LJ, Schmitz G, Pfrieger FW (2007) Glia-induced neuronal differentiation by transcriptional regulation. GLIA 55:1108-1122

102. Rimer M, Prieto AL, Weber JL, Colasante C, Ponomareva O, Fromm L, Schwab MH, Lai C, Burden SJ (2004) Neuregulin-2 is synthesized by motor neurons and terminal Schwann cells and activates acetylcholine receptor transcription in muscle cells expressing ErbB4. Mol Cell Neurosci 26:271-281

103. Ponomareva ON, Fischer TM, Lai C, Rimer M (2006) Schwann cell-derived neuregulin-2alpha can function as a cell-attached activator of muscle acetylcholine receptor expression. GLIA 54:630-637

104. Kummer TT, Misgeld T, Sanes JR (2006) Assembly of the postsynaptic membrane at the neuromuscular junction: paradigm lost. Curr Opin Neurobiol 16:74-82

105. Augustin H, Grosjean Y, Chen K, Sheng Q, Featherstone DE (2007) Nonvesicular release of glutamate by glial xCT transporters suppresses glutamate receptor clustering in vivo. J Neurosci 27:111-123

106. Cao G, Ko CP (2007) Schwann cell-derived factors modulate synaptic activities at developing neuromuscular synapses. J Neurosci 27:6712-6722

107. Mauch DH, Nägler K, Schumacher S, Göritz C, Müller EC, Otto A, Pfrieger FW (2001) CNS synaptogenesis promoted by gliaderived cholesterol. Science 294:1354-1357

108. Nieweg K, Schaller H, Pfrieger FW (2009) Marked differences in cholesterol synthesis between neurons and glial cells from postnatal rats. J Neurochem 109:125-134

109. Kretz O, Fester L, Wehrenberg U, Zhou L, Brauckmann S, Zhao S, Prange-Kiel J, Naumann T, Jarry H, Frotscher M, Rune GM (2004) Hippocampal synapses depend on hippocampal estrogen synthesis. J Neurosci 24:5913-5921

110. Brewer GJ, Boehler MD, Jones TT, Wheeler BC (2008) NbActiv4 medium improvement to Neurobasal/B27 increases neuron synapse densities and network spike rates on multielectrode arrays. J Neurosci Methods 170:181-187

111. Hama H, Hara C, Yamaguchi K, Miyawaki A (2004) PKC signaling mediates global enhancement of excitatory synaptogenesis in neurons triggered by local contact with astrocytes. Neuron 41:405-415

112. Stevens B, Allen NJ, Vazquez LE, Howell GR, Christopherson KS, Nouri N, Micheva KD, Mehalow AK, Huberman AD, Stafford B, Sher A, Litke AM, Lambris JD, Smith SJ, John SW, Barres BA (2007) The classical complement cascade mediates CNS synapse elimination. Cell 131:1164-1178

113. Moon JI, Birren SJ (2008) Target-dependent inhibition of sympathetic neuron growth via modulation of a BMP signaling pathway. Dev Biol 315:404-417

114. Kasthuri N, Lichtman JW (2004) Structural dynamics of synapses in living animals. Curr Opin Neurobiol 14:105-111

115. Walsh DM, Selkoe DJ (2007) A beta oligomers-a decade of discovery. J Neurochem 101:1172-1184

116. Knobloch M, Mansuy IM (2008) Dendritic spine loss and synaptic alterations in Alzheimer's disease. Mol Neurobiol 37:7382

117. Nishida H, Okabe S (2007) Direct astrocytic contacts regulate local maturation of dendritic spines. J Neurosci 27:331-340

118. Sanes JR, Lichtman JW (1999) Development of the vertebrate neuromuscular junction. Annu Rev Neurosci 22:389-442
119. Bishop DL, Misgeld T, Walsh MK, Gan WB, Lichtman JW (2004) Axon branch removal at developing synapses by axosome shedding. Neuron 44:651-661

120. Song JW, Misgeld T, Kang H, Knecht S, Lu J, Cao Y, Cotman SL, Bishop DL, Lichtman JW (2008) Lysosomal activity associated with developmental axon pruning. J Neurosci 28:89939001

121. Jefferis GS, Marin EC, Watts RJ, Luo L (2002) Development of neuronal connectivity in Drosophila antennal lobes and mushroom bodies. Curr Opin Neurobiol 12:80-86

122. Awasaki T, Ito K (2004) Engulfing action of glial cells is required for programmed axon pruning during Drosophila metamorphosis. Curr Biol 14:668-677

123. Watts RJ, Schuldiner O, Perrino J, Larsen C, Luo L (2004) Glia engulf degenerating axons during developmental axon pruning. Curr Biol 14:678-684

124. Logan MA, Freeman MR (2007) The scoop on the fly brain: glial engulfment functions in Drosophila. Neuron Glia Biol 3:63-74

125. Bachoo RM, Kim RS, Ligon KL, Maher EA, Brennan C, Billings N, Chan S, Li C, Rowitch DH, Wong WH, DePinho RA (2004) Molecular diversity of astrocytes with implications for neurological disorders. Proc Natl Acad Sci USA 101:8384-8389

126. Lovatt D, Sonnewald U, Waagepetersen HS, Schousboe A, He W, Lin JH, Han X, Takano T, Wang S, Sim FJ, Goldman SA, Nedergaard M (2007) The transcriptome and metabolic gene signature of protoplasmic astrocytes in the adult murine cortex. J Neurosci 27:12255-12266

127. Cahoy JD, Emery B, Kaushal A, Foo LC, Zamanian JL, Christopherson KS, Xing Y, Lubischer JL, Krieg PA, Krupenko SA, Thompson WJ, Barres BA (2008) A transcriptome database for astrocytes, neurons, and oligodendrocytes: a new resource for understanding brain development and function. J Neurosci 28:264-278

128. Hochstim C, Deneen B, Lukaszewicz A, Zhou Q, Anderson DJ (2008) Identification of positionally distinct astrocyte subtypes whose identities are specified by a homeodomain code. Cell 133:510-522

129. Roesch K, Jadhav AP, Trimarchi JM, Stadler MB, Roska B, Sun BB, Cepko CL (2008) The transcriptome of retinal Muller glial cells. J Comp Neurol 509:225-238

130. D'Antonio M, Michalovich D, Paterson M, Droggiti A, Woodhoo A, Mirsky R, Jessen KR (2006) Gene profiling and bioinformatic analysis of Schwann cell embryonic development and myelination. GLIA 53:501-515

131. Lafon-Cazal M, Adjali O, Galeotti N, Poncet J, Jouin P, Homburger V, Bockaert J, Marin P (2003) Proteomic analysis of astrocytic secretion in the mouse. Comparison with the cerebrospinal fluid proteome. J Biol Chem 278:24438-24448

132. Yang JW, Suder P, Silberring J, Lubec G (2005) Proteome analysis of mouse primary astrocytes. Neurochem Int 47:159 172

133. Rohl C, Armbrust E, Kolbe K, Lucius R, Maser E, Venz S, Gulden M (2008) Activated microglia modulate astroglial enzymes involved in oxidative and inflammatory stress and increase the resistance of astrocytes to oxidative stress in vitro. GLIA 56:1114-1126

134. Doyle JP, Dougherty JD, Heiman M, Schmidt EF, Stevens TR, Ma G, Bupp S, Shrestha P, Shah RD, Doughty ML, Gong S, Greengard P, Heintz N (2008) Application of a translational profiling approach for the comparative analysis of CNS cell types. Cell 135:749-762

135. Oldham MC, Konopka G, Iwamoto K, Langfelder P, Kato T, Horvath S, Geschwind DH (2008) Functional organization of the transcriptome in human brain. Nat Neurosci 11:1271-1282 
136. Bushong EA, Martone ME, Jones YZ, Ellisman MH (2002) Protoplasmic astrocytes in CA1 stratum radiatum occupy separate anatomical domains. J Neurosci 22:183-192

137. Nimmerjahn A, Kirchhoff F, Kerr JN, Helmchen F (2004) Sulforhodamine 101 as a specific marker of astroglia in the neocortex in vivo. Nat Methods 1:31-37

138. Wilhelmsson U, Bushong EA, Price DL, Smarr BL, Phung V, Terada M, Ellisman MH, Pekny M (2006) Redefining the concept of reactive astrocytes as cells that remain within their unique domains upon reaction to injury. Proc Natl Acad Sci USA 103:17513-17518

139. Hirrlinger J, Hulsmann S, Kirchhoff F (2004) Astroglial processes show spontaneous motility at active synaptic terminals in situ. Eur J NeuroSci 20:2235-2239

140. Vasenkova I, Luginbuhl D, Chiba A (2006) Gliopodia extend the range of direct glia-neuron communication during the CNS development in Drosophila. Mol Cell Neurosci 31:123-130

141. Benediktsson AM, Schachtele SJ, Green SH, Dailey ME (2005) Ballistic labeling and dynamic imaging of astrocytes in organotypic hippocampal slice cultures. J Neurosci Methods 141:4153

142. Haber M, Zhou L, Murai KK (2006) Cooperative astrocyte and dendritic spine dynamics at hippocampal excitatory synapses. J Neurosci 26:8881-8891

143. Genoud C, Quairiaux C, Steiner P, Hirling H, Welker E, Knott GW (2006) Plasticity of astrocytic coverage and glutamate transporter expression in adult mouse cortex. PLoS Biol 4:e343

144. Hama K, Arii T, Katayama E, Marton M, Ellisman MH (2004) Tri-dimensional morphometric analysis of astrocytic processes with high voltage electron microscopy of thick Golgi preparations. J Neurocytol 33:277-285

145. Lichtman JW, Smith SJ (2008) Seeing circuits assemble. Neuron 60:441-448

146. Denk W, Horstmann H (2004) Serial block-face scanning electron microscopy to reconstruct three-dimensional tissue nanostructure. PLoS Biol 2:e329

147. Lucic V, Forster F, Baumeister W (2005) Structural studies by electron tomography: from cells to molecules. Annu Rev Biochem 74:833-865
148. Ganat YM, Silbereis J, Cave C, Ngu H, Anderson GM, Ohkubo Y, Ment LR, Vaccarino FM (2006) Early postnatal astroglial cells produce multilineage precursors and neural stem cells in vivo. J Neurosci 26:8609-8621

149. Hirrlinger PG, Scheller A, Braun C, Hirrlinger J, Kirchhoff F (2006) Temporal control of gene recombination in astrocytes by transgenic expression of the tamoxifen-inducible DNA recombinase variant CreERT2. GLIA 54:11-20

150. Slezak M, Goritz C, Niemiec A, Frisen J, Chambon P, Metzger D, Pfrieger FW (2007) Transgenic mice for conditional gene manipulation in astroglial cells. GLIA 55:1565-1576

151. Chow LM, Zhang J, Baker SJ (2008) Inducible Cre recombinase activity in mouse mature astrocytes and adult neural precursor cells. Transgenic Res 17:919-928

152. Weimer JM, Stanco A, Cheng JG, Vargo AC, Voora S, Anton ES (2008) A BAC transgenic mouse model to analyze the function of astroglial SPARCL1 (SC1) in the central nervous system. GLIA 56:935-941

153. Mori T, Tanaka K, Buffo A, Wurst W, Kuhn R, Gotz M (2006) Inducible gene deletion in astroglia and radial glia - a valuable tool for functional and lineage analysis. GLIA 54:21-34

154. Bracchi-Ricard V, Brambilla R, Levenson J, Hu WH, Bramwell A, Sweatt JD, Green EJ, Bethea JR (2008) Astroglial nuclear factor-kappaB regulates learning and memory and synaptic plasticity in female mice. J Neurochem 104:611-623

155. Pascual O, Casper KB, Kubera C, Zhang J, Revilla-Sanchez R, Sul JY, Takano H, Moss SJ, McCarthy K, Haydon PG (2005) Astrocytic purinergic signaling coordinates synaptic networks. Science 310:113-116

156. Sweger EJ, Casper KB, Scearce-Levie K, Conklin BR, McCarthy KD (2007) Development of hydrocephalus in mice expressing the G(i)-coupled GPCR Ro1 RASSL receptor in astrocytes. J Neurosci 27:2309-2317

157. Colin A, Faideau M, Dufour N, Auregan G, Hassig R, Andrieu T, Brouillet E, Hantraye P, Bonvento G, Deglon N (2008) Engineered lentiviral vector targeting astrocytes in vivo. GLIA (in press)

158. Freeman MR, Doherty J (2006) Glial cell biology in Drosophila and vertebrates. Trends Neurosci 29:82-90 